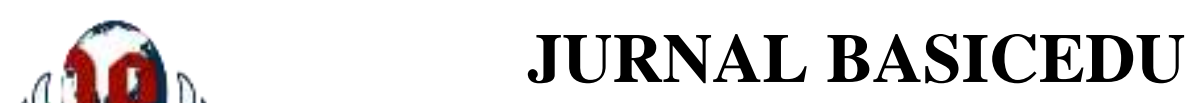

Volume 5 Nomor 5 Tahun 2021 Halaman 3778 - 3790

Research \& Learning in Elementary Education

https://jbasic.org/index.php/basicedu

PATLATAM

\title{
Pengembangan Instrumen Tes Literasi Sains pada Tema 8 Lingkungan Sahabat Kita untuk Siswa Sekolah Dasar
}

\author{
Tuhim Setia Ulva $^{1 凶}$, Dian Samitra ${ }^{2}$, R. Angga Bagus Kusnanto ${ }^{3}$ \\ STKIP-PGRI Lubuklinggau,Indonesia ${ }^{1,2,3}$ \\ E-mail: tuhimsetiaulva@gmail.com ${ }^{1}$, dian.sampitra@gmail.com ${ }^{2}, \underline{\text { radenangga4@gmail.com }}^{3}$
}

\begin{abstract}
Abstrak
Penelitian ini bertujuan untuk mengembangkan sebuah produk berupa Instrumen Tes Literasi Sains pada Tema 8 Lingkungan Sahabat Kita untuk Kelas V SD Negeri 2 Sugihwaras yang valid dan praktis untuk digunakan dalam pembelajaran. Populasi sampel yang digunakan adalah siswa kelas V SD Negeri 2 sugihwaras sebanyak 4 siswa uji one to one dan 8 siswa uji kelompok kecil. Jenis penelitian ini peneliti menggunakan pengembangan model ADDIE (Analysis, Desain, Devlopment, Implimentation dan Evaluation). Teknik Pengumpulan data menggunakan angket validasi ahli bahasa, ahli media, ahli materi dan angket kepraktisan guru dan siswa. Berdasarkan hasil analisis oleh ketiga ahli yaitu ahli bahasa, ahli media dan ahli materi menunjukkan bahwa Instrumen tes literasi sains pada tema 8 lingkungan sahabat kita memenuhi kriteria valid dengan skor rata-rata 4,3. Sedangkan hasil analisis lembar kepraktisan guru memperoleh presentase 94, 55\% dan analisis kepraktisan siswa memperoleh 92,42\% dengan kategori sangat praktis. Sehingga Instrumen tes literasi sains pada tema 8 lingkungan sahabat kita memenuhi kriteria valid dan praktis serta dapat digunakan dalam proses pembelajaran.
\end{abstract}

Kata Kunci: Pengembangan, Instrumen Tes, Literasi Sains.

\section{Abstract}

This research animed to develop a product in the form of a Science Literacy Test Instrument on Theme 8 Our Friends Environment for Class V SD Negeri 2 Sugihwaras that is valid and practical to use in learning. The sample population used was the fifth grade students of SD Negeri 2 Sugihwaras as many as 4 students for the one to one test and 8 students for the small group test. This type of research researchers use the ADDIE model development (Analysis, Design, Development, Implementation and Evaluation). The data collection technique used a validation questionnaire of linguists, media experts, material experts and practicality questionnaires for teachers and students. Based on the results of the analysis by the three experts, namely linguists, media experts and material experts, it showed that the scientific literacy test instrument on the theme 8 of our friend's environment met the valid criteria with an average score of 4.3. While the results of the analysis of the practicality of the teacher obtained a percentage of $94,55 \%$ and the analysis of the practicality of the students obtained $92.42 \%$ with a very practical category. So that the scientific literacy test instrument on the theme 8 of our friend's environment meets the valid and practical criteria and can be used in the learning process.

Keywords: Development, Test Instruments, Scientific Literacy.

Copyright (c) 2021 Tuhim Setia Ulva, Dian Samitra, R. Angga Bagus Kusnanto

Corresponding author :

Email : tuhimsetiaulva@gmail.com

DOI : https://doi.org/10.31004/basicedu.v5i5.1394

ISSN 2580-3735 (Media Cetak)

ISSN 2580-1147 (Media Online)

Jurnal Basicedu Vol 5 No 5 Tahun 2021

p-ISSN 2580-3735 e-ISSN 2580-1147 


\section{PENDAHULUAN}

Pendidikan merupakan suatu usaha sadar yang dilakukan untuk merubah sikap atau tingkah laku melalui proses pembelajaran. (Kusnanto, 2019: 159) Pendidikan seharusnya hadir sebagai upaya untuk membentuk manusia yang berkepribadian, pendidikan tidak hanya memberikan pembelajran materi-materi yang ada disekolah saja tetapi juga untuk membentuk keribadian yang bertanggung jawab serta memahami norma-norma yang berlaku dimasyarakat. (Seran, 2019: 2) pendidikan adalah sistem yang terencana untuk mewujudkan proses pembelajaran, agar peserta didik secara aktif mengembangkan potensi dirinya agar memiliki pengendalian diri, kepribadian, kecerdasan, akhlak mulia serta keterampilan yang diperlukan di masyarakat, bangsa dan negara. Sistem pendidikan di Indonesia menetapkan kurikulum sebagai komponen pendidikan. (Melati \& Utanto, 2016:) Kurikulum 2013 adalah seperangkat rencana yang meliputi tujuan, kompetensi dasar serta hasil yang merujuk pada pendidikan karakter, terutama pada tingkat dasar yang akan menjadi fondasi pada tingkat berikutnya. dapat disimpulkan bahwa pendidikan merupakan landasan bagi seseorang untuk merubah sikap, tingkah laku dengan cara pemberian latihan melalui proses pembelajaran. (Minan \& Suhendro 2020: 5) Kurikulum merupakan suatu rencana yang memberi pedoman atau pegangan dalam proses kegiatan belajar-mengajar. Indonesia saat ini menggunakan kurikulum 2013 (K-13) dimana dalam penerapan kurikulum ini banyak melibatkan siswa dalam proses pembelajarannya. (Samitra et al., 2018: 2) Melalui pendidikan siswa dapat mengubah pola pikirnya untuk melakukan perbaikan dalam segala aspek kehidupan agar menjadi individu berkualitas yang diperlukan untuk dirinya sendiri, masyarakat, bangsa dan negara, serta mampu berinovasi dan mampu mencari solusi dari suatu permasalahan yang sedang berkembang.

Pada kurikulum guru diwajibkan untuk melakukan evaluasi. Hal ini dilakukan untuk mengetahui pemahaman siswa dalam pembelajaran dalam bentuk soal atau tugas. Belum banyak sekolah yang menggunakan literasi sains sebagai tolak ukur melatih kemampuan siswa dalam pembelajaran tematik. Setiawan, (2020: 2) mengemukakan literasi sains terdapat Lima aspek literasi sains terdiri atas peran sains, berpikir dan bekerja secara ilmiah, sains dan masyarakat, matematika dalam sains, serta motivasi dan kepercayaan terhadap sains. Melalui literasi sains siswa tidak hanya terpaku pada konsep-konsep yang ada dibuku tetapi lebih melibatkan siswa secara langsung, serta dapat mengembangkan kemampuan dalam mengemukakan pendapat seperti bertanya dan mencari jawaban berdasrkan bukti. Setiawan, (2020: 2) menyusun indikator keterampilan literasi saintifik menjadi 2 bagian, yakni: memahami metode penyelidikan yang mengarah pada pengetahuan ilmiah; serta mengatur, menganalisis, sekaligus menafsirkan data kuantitatif dan informasi ilmiah. (Yuliati, 2017: 22) Pada tingkat sekolah dasar Ilmu Pengetahuan Alam atau sains merupakan salah satu mata pelajaran yang menduduki peranan penting dalam pendidikan hal ini dikarenakan sains dapat menjadi bekal bagi peserta didik dalam menghadapi berbagai tantangan di era global.

Berdasarkan hasil wawancara dengan Ibu Supartiyah, S. Pd. SD wali kelas V SD Negeri 2 Sugihwaras, pada tanggal 20 November 2020 mengatakan bahwa terdapat kesulitan atau kendala-kendala yang ditemui saat pembelajaran berlangsung yaitu banyak siswa yang belum mencapai kriteria ketuntasan belajar (KKM) dalam pelajaran IPA dikarenakan guru belum menerapkan literasi sains untuk mengukur kemampuan siswa. Pentignya literasi sains yang digunakan oleh guru untuk megukur kemampuan siswa dalam memahami pembelajaran melalui pertanyaan-pertanyaan yang dijawab oleh siswa. Pentignya literasi sains yang digunakan oleh guru untuk megukur kemampuan siswa dalam memahami pembelajaran melalui pertanyaanpertanyaan yang dijawab oleh siswa. Oleh karena itu, literasi sains diharapkan dapat membantu siswa dalam meningkatkan pemahaman melalui tes-tes atau soal yang diberikan oleh guru. Dapat disimpulkan bahwa pengalaman mengajar dan belajar guna meningkatkan pemahaman siswa dengan memberikan tes melalui soal-soal yang mempunyai tingkat kesulitan yang berbeda dan lebih menarik perhatian siswa agar termotivasi dan terbiasa mengerjakan tes yang diberikan oleh guru. 
(Sohibun, 2017: 123) Pengembangan merupakan suatu proses atau langkah-langkah yang digunakan dalam mengembangkan suatu produk baru atau menyempurnakan produk yang sudah ada serta dapat di pertanggung jawabkan. (Tegeh \& Pudjawan, 2015: 2) mengemukakan bahwa pada tingkat desain materi pembelajaran dan pengembangan, sistematik sebagai aspek prosedural pendekatan sistem telah diwujudkan dalam banyak praktik metodologi untuk desain dan pengembangan teks, materi audiovisual, dan materi pembelajaran berbasis komputer. Menurut (Santoso, 2017: 25) instrumen adalah sebuah alat bantu yang dipilih dan digunakan oleh peneliti dalam kegiatan menggumpulkan data, agar kegiatan menjadi sistematis dan mudah. (Sudijono, 2011: 4) menilai adalah kegiatan kegiatan pengambilan keputusan terhadap sesuatu dengan mendasar pada suatu ukuran yaitu ukuran baik atau ukuran buruk. (Samatowa, 2018: 6) menjelaskan bahwa pengembangan pembelajaran sains pada anak ditujukan kepada empat hal yaitu: a) Pengembangan pembelajaran sains ditujukan agar siswa memiliki kemampuan memecahkan masalah melalui metode sains, sehingga anak dapat terampil dalam menyelesaikan berbagai hal yang dihadapinya, b) Pengembangan pembelajaran sains pada siswa ditujukan agar siswa memiliki sikap ilmiah, seperti melihat segala sesuatu dari berbagai sudut pandang agar siswa dapat berhati-hati terhadap informasi-informasi yang diterimanya serta bersifat terbuka, c) Pengembangan pembelajaran sains pada siswa ditujukan agar siswa mendapatkan pengetahuan dan informasi ilmiah, d) Pengembangan pembelajaran sains pada siswa ditujukan agar siswa lebih berminat dan tertarik untuk menghayati sains yang berada dan ditemukan dilingkungan dan alam sekitarnya. (Novanti, 2018: 2) Literasi sains meliputi rangkaian strategi yang digunakan siswa dalam memecahkan berbagai masalah yang ada di masyarakat (satria \& Egok, 2020: 15) Pembelajaran sains yang mampu menjembatani perpaduan antara budaya siswa dengan budaya ilmiah di sekolah akan dapat mengefektifkan proses belajar siswa.

Lingkungan sahabat kita merupakan topik dasar dalam pembelajaran tematik tema 8 pada jenjang Sekolah Dasar. Tema lingkungan sahabat kita di dalamnya terdapat materi yang terkait dengan lingkungan. Terdapat muatan literasi sains dalam topik ini, salah satunya yaitu menganalisis peran makhluk hidup terhadap permasalahan lingkungan, namun belum ada instrumen literasi sains yang berkaitan dengan topik lingkungan sahabat kita. Berdasarkan uraian di atas, penulis mengembangkan instrumen tes literasi sains pada tema 8 lingkungan sahabat kita di kelas V Sekolah Dasar Negeri 2 Sugihwaras.

\section{METODE PENELITIAN}

Model pengembangan yang digunakan dalam penelitian ini adalah model ADDIE. ADDIE pada dasarnya adalah sebuah hasil dari suatu hasil paradigma pengembangan. (Suryani, 2018: 125) Prosedur pengembangan untuk menghasilkan produk akhir berupa instrumen tes literasi sains yang digunakan sebagai tes di kelas V SD. Dalam penelitian ini, peneliti mengadaptasi prosedur penelitian menurut ADDIE yang disesuaikan dengan kebutuhan peneliti. Prosedur penelitian pengembangan ADDIE melalui lima langkah yaitu: (1) Analyze (analisis kesulitan dan analisis kebutuhan), (2) Design (mendesain pengembangan instrument tes, (3) Development (pengembangan instrument tes literasi sains), (4) Implementation (penerapan pengembangan), (5) Evaluation Dalam prosedur pengembangan berupa instrument tes literasi sains, yang dikhususkan dan disesuaikan dengan kebutuhan dalam literasi sains pada siswa kelas V SD Negeri 2 Sugihwaras. Instrumen tes diuji cobakan kepada siswa SD Negeri 2 Sugihwaras kelas V kepada siswa sebanyak 4 orang pada uji one to one, dan 8 orang pada tahap uji kelompok kecil. Kemudian siswa diberikan angket untuk dijawab dan menjadi analisis peneliti apakah instrumen tes yang dibuat perlu dilakukan revisi atau tidak. 
3781 Pengembangan Instrumen Tes Literasi Sains pada Tema 8 Lingkungan Sahabat Kita untuk Siswa Sekolah Dasar - Tuhim Setia Ulva, Dian Samitra, R. Angga Bagus Kusnanto

DOI: https://doi.org/10.31004/basicedu.v5i5.1394

\section{Teknik Pengumpulan Data}

Dalam pengumpulan data peneliti dapat menggunakan berbagai teknik pengumpulan data yaitu sebagai berikut:

Observasi, (Sugiyono, 2019: 294) observasi adalah dasar semua ilmu pengetahuan, dimana para ilmuan hanya dapat bekerja berdasarkan data, yaitu fakta mengenai dunia kenyataan yang diperoleh melalui observasi. Dapat disimpulkan bahwa observasi dilakukan untuk mencari bukti yang ada di dunia nyata yang dapat dilakukan melalui observasi.

Wawancara, Wawancara digunakan sebagai teknik pengumpulan data yang dilakukan oleh peneliti dalam melakukan studi pendahuluan untuk menemukan permasalahan yang diteliti dan mengetahui hal-hal dari responden yang lebih mendalam (Sugiyono, 2019: 295) mengemukakan bahwa anggapan yang perlu dipegang peneliti dalam menggunakan metode interview dan juga kuesioner (angket) adalah sebagai berikut: 1) Bahwa subyek (responden) adalah orang yang paling tahu tentang dirinya sendiri, 2) Bahwa apa yang dinyatakan oleh subyek kepada peneliti adalah benar dan dapat dipercaya, 3) Bahwa interprestasi subyek tentang pertanyaan-pertanyaan yang diajukan peneliti kepadanya adalah sama dengan apa yang dimaksudkan oleh peneliti. Berdasarkan pernyataan diatas dapat disimpulkan bahwa wawancara merupakan sebuah metode yang digunakan dalam teknik pengumpulan data untuk menemukan permasalahan yang harus diteliti dari respondennya untuk mengetahui hal-hal lebih mendalam dari respondennya. Dalam melakukan wawancara peneliti menyiapkan instrumen yang berisi pertanyaan-pertanyaan.

Kuesioner (Angket), Menurut (Sugiyono, 2019: 201) Kuesioner merupakan teknik pengumpulan data yang dilakukan dengan cara memberi seperangkat pertanyaan atau pernyataan tertulis kepada responden untuk dijawab. Angket diberikan kepada ahli validasi yaitu ahli bahasa, media dan ahli materi untuk diuji apakah produk yang dikembangkan layak untuk diujicobakan. Angket kepraktisan peserta didik dan angket guru untuk mengetahui respon peserta didik dan respon guru terhadap instrument tes yang dikembangkan. Karakteristik instrumen mencakup kesahihan (validitas) dan kehandalan (reliabilitas). (Zubaidillah, 2018: 1) Penilaian merupakan bagian dalam sistem pendidikan saat ini. Peningkatan kualitas pendidikan dapat dilihat dari nilai-nilai yang diperoleh siswa.

\section{Teknik Analisis Data}

\section{a. Analisis Kevalidan}

Teknik analisis data merupakan teknik yang digunakan untuk menganalisis data yang didapatkan dalam proses penelitian. (Zaenal Arifin, 2017: 30) menjelaskan bahwa validitas berasal dari kata "Validity" yang mempunyai arti sejauh ketepatan dan kecermatan suatu alat ukur dalam melakukan fungsi ukurnya Tujuan dilakukan analisis data adalah untuk mengetahui kevalidan dan kepraktisan perangkat pembelajaran dengan instrumen tes literasi sains. Analisis kevalidan dapat dilakukan sebagai berikut:

1) Tabulasi data

Pedoman pemberian skor instrumen tes literasi sains untuk ahli bahasa, ahli materi dan ahli media diisi dengan ketentuan berdasarkan tabel berikut:

Tabel 1

Pedoman Pemberian Skor Penialian Kevalidan Literasi Sains

\begin{tabular}{cc}
\hline Skor & Kriteria \\
\hline 5 & Sangat Baik \\
\hline 4 & Baik \\
\hline 3 & Cukup Baik \\
\hline 2 & kurang Baik \\
\hline 1 & Tidak Baik \\
\hline & (Sartilah, 2021: 42)
\end{tabular}


3782 Pengembangan Instrumen Tes Literasi Sains pada Tema 8 Lingkungan Sahabat Kita untuk Siswa Sekolah Dasar - Tuhim Setia Ulva, Dian Samitra, R. Angga Bagus Kusnanto

DOI: https://doi.org/10.31004/basicedu.v5i5.1394

2) Menghitung skor rata-rata

Menghitung skor rata-rata dari seluruh aspek dapat dihitung menurut Widiyoko dalam Sartilah, 2021: 43. Dengan rumus sebagai berikut:

$$
\bar{X}=\frac{\Sigma x}{N}
$$

Keterangan:

$\bar{x} \quad=$ Skor rata-rata seluruh aspek

$\Sigma \mathrm{x} \quad=$ Jumlah skor seluruh aspek

$\mathrm{N} \quad=$ Banyaknya butir pertanyaan

3) Mengubah skor rata-rata

Tabel 2

Pedoman Pengubah Skor Rata-Rata

\begin{tabular}{cc}
\hline Interval Rata-rata Skor & Kriteria \\
\hline$x>3,4$ & Sangat Baik \\
\hline $2,8<x \leq 3,4$ & Baik \\
\hline $2,2<x \leq 2,8$ & Cukup \\
\hline $1,6<x \leq 2,2$ & Kurang \\
\hline $1,6 \leq x$ & Sangat Kurang \\
\hline & (Sartilah, 2021: 43)
\end{tabular}

a. Analisis Kepraktisan

Zaenal Arifin (2017: 264) mengemukakan bahwa kepraktisan adalah syarat suatu tes standar. Kepraktisan Instrumen literasi sains dapat dilihat dari hasil identifikasi angket kepraktisan siswa dan angket kepraktisan guru. Hasil penelitian oleh siswa pada lembar kepraktisan dicari dengan cara berikut:

1) Angket respon siswa dan respon guru diberikan skor untuk setiap item dengan jawaban yang berbeda yaitu dapat dilihat sebagai berikut:

Tabel 3

Pemberian Nilai Skor Angket Siswa

\begin{tabular}{cc}
\hline Skor & Kriteria \\
\hline 1 & Ya \\
\hline 2 & Tidak \\
\hline
\end{tabular}

Tabel 4

Penilaian Angket Guru

\begin{tabular}{cc}
\hline Skor & Kriteria \\
\hline 5 & Sangat Baik \\
\hline 4 & Baik \\
\hline 3 & Cukup Baik \\
\hline 2 & Kurang Baik \\
\hline 1 & Tidak Baik \\
\hline
\end{tabular}


3783 Pengembangan Instrumen Tes Literasi Sains pada Tema 8 Lingkungan Sahabat Kita untuk Siswa Sekolah Dasar - Tuhim Setia Ulva, Dian Samitra, R. Angga Bagus Kusnanto

DOI: https://doi.org/10.31004/basicedu.v5i5.1394

2) Pemberian nilai validitas dengan rumus berikut:

Tingkat kepraktisan $=\frac{\text { Jumlah yang diperoleh }}{\text { Jumlah total }} \times 100 \%$

(Santoso, 2017: 261)

3) Mencocokkan rata-rata kepraktisan dengan kriteria kepraktisan instrument tes

Tabel 5

Kriteria Kepraktisan Instrumet Tes Literasi Sains

\begin{tabular}{cc}
\hline Interval Rata-rata Skor & Klarifikasi \\
\hline $81 \%-100 \%$ & Sangat Praktis \\
\hline $61 \%-80 \%$ & Praktis \\
\hline $41 \%-60 \%$ & Cukup Praktis \\
\hline $21 \%-40 \%$ & Kurang Praktis \\
\hline $0 \%-2-\%$ & Tidak Pratis \\
\hline &
\end{tabular}

\section{HASIL DAN PEMBAHASAN}

Pengembangan instrumen tes literasi sains ini diujikan pada 28 Juli 2021. Produk akhir penelitian ini adalah instrumen tes berbasis literasi sains pada tema 8 lingkungan sahabat kita untuk siswa kelas V Sekolah Dasar Negeri 2 Sugihwaras. Instrumen tes yang digunakan dalam penelitian ini berupa soal uraian berbasis literasi sains. Dalam pengembangan ADDIE terdapat beberapa tahapan yaitu: tahap analysis (analisis), tahap design (perancangan) tahap devlopment (pengembangan), tahap evaluation (evaluasi). Tahapan tersebut harus dilalui penulis agar instrumen tes literasi sains pada tema 8 lingkungan sahabat kita untuk siswa kelas $\mathrm{V}$ valid dan praktis. Berikut ini tahapan-tahapan yang telah dilalui penulis:

\section{Tahap Analisis}

Tahap awal pengembangan instrumen tes literasi sains adalah analisis kebutuhan. Analisis kebutuhan produk yang dikembangkan berkaitan dengan kondisi nyata dilapangan sesuai dengan kebutuhan. Analisis kebutuhan pembelajaran merupakan tahap mencari tahu produk, berupa instrumen tes literasi sains yang dibutuhkan oleh guru dan siswa pada tema 8 lingkungan sahabat kita untuk siswa kelas V SD Negeri 2 Sugihwaras.

\section{Tahap Design (Perancangan)}

Proses desain instrumen tes, sebelum peneliti mulai mengembangkan desain instrumen tes terlebih dahulu peneliti memahami cara pengembangan dari beberapa referensi tentang pembuatan instrumen tes. Saran dari dosen pembimbing dan dosen penguji sangat membantu peneliti yang masih pemula dalam mengembangkan bahan ajar. Sebelum proses validasi peneliti juga meminta masukan dari beberapa teman serta beberapa guru tentang instrumen tes yang dikembangkan. Berikut ini adalah bentuk penyusunan instrumen tes literasi sains yang ingin dibuat oleh peneliti yaitu sebagai berikut

\section{Tabel 6}

Format penyusunan instrumen tes literasi sains

\begin{tabular}{cll}
\hline No. & Unsur Instrumen Tes & \multicolumn{1}{c}{ Deskripsi Instrumen Tes } \\
\hline 1. & Cover depan & $\begin{array}{l}\text { Halaman depan berisi judul, kelas, identitas } \\
\text { siswa, logo Pendidikan, dan nama pengarang }\end{array}$ \\
\hline 2. & Petunjuk Umum & Berisi petunjuk bagi siswa dalam menggunakan \\
\hline
\end{tabular}


3784 Pengembangan Instrumen Tes Literasi Sains pada Tema 8 Lingkungan Sahabat Kita untuk Siswa Sekolah Dasar - Tuhim Setia Ulva, Dian Samitra, R. Angga Bagus Kusnanto

DOI: https://doi.org/10.31004/basicedu.v5i5.1394

\begin{tabular}{lll}
\hline & & tes literasi sains \\
\hline 3. & Petunjuk penggerjaan soal & $\begin{array}{l}\text { Berisi petunjuk cara pengerjaan soal oleh siswa } \\
\text { serta waktu pengerjaan. }\end{array}$ \\
\hline 4. & Materi & $\begin{array}{l}\text { Materi tematik tema } 8 \text { lingkungan sahabat kita, } \\
\text { sutema } 1 \text { manusia dan lingkungan, subtema 2 } \\
\text { perubahan lingkungan dan subtema } 3 \text { upaya } \\
\text { pelestarian lingkungan. }\end{array}$ \\
\hline 5. & Literasi sains & $\begin{array}{l}\text { Pembelajaran yang mengaitkan materi } \\
\text { pembelajaran dengan kemampuan literasi yang } \\
\text { dimiliki siswa agar siswa mampu menjawab } \\
\text { pertanyaan berdasarkan bukti nyata yang ada } \\
\text { dilingkungan sekitarnya. }\end{array}$ \\
\hline 6. & Tugas Individu & $\begin{array}{l}\text { Tes diberikan setelah pembelajaran tema 8 } \\
\text { selesai }\end{array}$ \\
\hline 7. & Cover belakang & Sebagai sampul belakang \\
\hline
\end{tabular}

\section{Tahap Development (Pengembangan)}

Instrumen tes dikembangkan menjadi 15 butir soal uraian, dengan rincian sebagai berikut:

1) lima butir soal subtema 1 manusia dan lingkungan.

2) lima butir soal subtema 2 perubahan lingkungan.

3) lima butir soal subtema upaya pelestarian lingkungan.

Instrumen tes yang digunakan mencakup domain kognitif $\mathrm{C} 1$ sampai $\mathrm{C} 5$, yaitu pengetahuan (C1), pemahaman (C2), aplikasi (C3), analisis (C4) dan evaluasi (C5).

\section{Tahap Implementation (Penerapan)}

Instrumen tes dilakukan validasi terlebih dahulu sebelum digunakan, validasi yang dilakukan adalah validasi bahasa, validasi media dan validasi materi yang dilakukan oleh tim ahli. Kemudian diuji cobakan kepada siswa SD Negeri 2 Sugihwaras kelas V Tahun Ajaran 2020/2021 sebanyak 4 orang pada uji one to one, dan 8 orang pada tahap uji kelompok kecil. Kemudian siswa diberikan angket untuk dijawab dan menjadi analisis peneliti apakah instrumen tes yang dibuat perlu dilakukan revisi atau tidak.

Pada penelitian ini instrumen yang digunakan berupa angket. Dua angket yang digunakan dalam penelitian ini yaitu angket untuk menilai kevalidan dan kepraktisan. Uraian angket penilaian kevalidan instrumen tes dan kepraktisan instrumen tes sebagai berikut:

\section{a. Hasil uji Validasi instrumen tes}

Angket penilaian validasi pada penelitian ini terdiri 35 pertanyaan disusun dengan skala Likert dengan kategori jawaban 5, 4, 3, 2 dan 1 dengan kriteria berturut-turut sangat baik, baik, cukup baik, kurang baik, tidak baik.

Berikut ini nama-nama validator pada pengembangan Instrumen tes literasi sains.

Tabel 7

Nama-Nama Validator

\begin{tabular}{clcc}
\hline No & \multicolumn{1}{c}{ Nama Validator } & Ahli & Validator \\
\hline 1 & Agung Nugroho, M. Pd. & Bahasa dan Sastra Indonesia & Bahasa \\
\hline 2 & Supartiyah, S. Pd. SD. & Materi Tematik & Materi \\
\hline 3 & Dr. Dodik Mulyono, M. Pd. & Media Pendidikan & Media \\
\hline
\end{tabular}

Hasil penilaian dari ketiga ahli diatas akan dianalisis untuk mengetahui validitas instrumen tes literasi sains pada tema VIII lingkungan sahabat kita untuk siswa kelas V SD Negeri 2 Sugihwaras. Berikut ini hasil dari penilaian ahli bahasa yang telah dianalisis oleh peneliti dapat dilihat sebagai berikut: 
3785 Pengembangan Instrumen Tes Literasi Sains pada Tema 8 Lingkungan Sahabat Kita untuk Siswa Sekolah Dasar - Tuhim Setia Ulva, Dian Samitra, R. Angga Bagus Kusnanto

DOI: https://doi.org/10.31004/basicedu.v5i5.1394

Tabel 8

Hasil Analisis Validasi Ahli Bahasa

\begin{tabular}{|c|c|c|c|}
\hline Aspek yang dinilai & Indikator penilaian & $\begin{array}{l}\text { Nilai/ } \\
\text { skor }\end{array}$ & Kategori \\
\hline \multirow[t]{2}{*}{$\begin{array}{c}\text { Kesesuaian Dengan } \\
\text { Perkembangan Siswa }\end{array}$} & $\begin{array}{l}\text { Kesesuaian bahasa dengan } \\
\text { tingkat berfikir siswa }\end{array}$ & 4 & Baik \\
\hline & $\begin{array}{l}\text { Kesesuaian bahasa dengan } \\
\text { tingkat emosi dan sosial } \\
\text { siswa }\end{array}$ & 4 & Baik \\
\hline $\begin{array}{c}\text { Kemampuan } \\
\text { Memotivasi Siswa }\end{array}$ & $\begin{array}{lr}\text { Penggunaan } & \text { bahasa } \\
\text { mendorong } & \text { siswa untuk } \\
\text { mencari } & \text { jawaban } \\
\text { berdasarkan } & \text { bukti } \\
\text { nyatayang } & \text { ada } \\
\text { dilingkungan sekitar } & \\
\end{array}$ & 4 & Baik \\
\hline \multirow[t]{10}{*}{$\begin{array}{c}\text { Kesesuaian Dengan } \\
\text { Kaidah Bahasa } \\
\text { Indonesia Yang Benar }\end{array}$} & $\begin{array}{lrr}\text { Rumus } & \text { soal } & \text { tidak } \\
\text { menggunakan } & \text { kata-kata } \\
\text { atau kalimat } & \text { yang } \\
\text { menimbulkan ambiguitas }\end{array}$ & 5 & Sangat Baik \\
\hline & $\begin{array}{l}\text { Butir soal menggunakan } \\
\text { bahasa Indonesia yang } \\
\text { baik dan benar }\end{array}$ & 5 & Sangat Baik \\
\hline & Kebakuan kata & 4 & Baik \\
\hline & Kelugasan kata & 4 & Baik \\
\hline & $\begin{array}{l}\text { Penggunaan kata } \\
\text { komunikatif }\end{array}$ & 4 & Baik \\
\hline & Ketepatan struktur kalimat & 4 & Baik \\
\hline & Keefektifan kalimat & 4 & Baik \\
\hline & $\begin{array}{l}\text { Kemudahan memahami } \\
\text { Bahasa }\end{array}$ & 5 & Sangat Baik \\
\hline & $\begin{array}{l}\text { Kesesuaian soal dengan } \\
\text { materi }\end{array}$ & 5 & Sangat Baik \\
\hline & $\begin{array}{lll}\begin{array}{l}\text { Kejelasan kalimat pada } \\
\text { materi }\end{array} & \\
\end{array}$ & 4 & Baik \\
\hline Total & & 56 & \\
\hline
\end{tabular}

Berdasarkan hasil dari penilaian ahli materi yang telah dianalisis untuk mengetahui validitas instrumen tes literasi sains. Adapun hasil validasi yang telah dianalisis sebagai berikut.

Tabel 9

Hasil Analisis Validasi Ahli Materi

\begin{tabular}{clcc}
\hline $\begin{array}{c}\text { Aspek yang } \\
\text { dinilai }\end{array}$ & \multicolumn{1}{c}{ Indikator Penilaian } & Nilai/Skor & Kategori \\
\hline $\begin{array}{c}\text { Aspek } \\
\text { kelayakan } \\
\text { materi }\end{array}$ & $\begin{array}{l}\text { Soal sesuai dengan materi tema } 8 \\
\text { Lingkungan sahabat kita }\end{array}$ & $\mathbf{5}$ & Sangat Baik \\
\cline { 2 - 4 } & Batasan pertanyaan dan jawaban jelas & $\mathbf{3}$ & Cukup Baik \\
\cline { 2 - 5 } & $\begin{array}{l}\text { Isi materi sesuai dengan lingkungan } \\
\text { yang ada ditempat tinggal }\end{array}$ & $\mathbf{5}$ & Sangat Baik \\
\cline { 2 - 4 } & $\begin{array}{l}\text { Isi materi sesuai dengan jenjang jenis } \\
\text { sekolah atau tingkat kelas }\end{array}$ & $\mathbf{5}$ & Sangat Baik \\
\cline { 2 - 5 } & Rumusan kalimat soal atau pertanyaan & $\mathbf{4}$ & Baik \\
\hline
\end{tabular}


3786 Pengembangan Instrumen Tes Literasi Sains pada Tema 8 Lingkungan Sahabat Kita untuk Siswa Sekolah Dasar - Tuhim Setia Ulva, Dian Samitra, R. Angga Bagus Kusnanto

DOI: https://doi.org/10.31004/basicedu.v5i5.1394

\begin{tabular}{|c|c|c|}
\hline $\begin{array}{l}\text { harus menggunakan kata Tanya atau } \\
\text { kata perintah yang menuntut jawaban } \\
\text { terurai }\end{array}$ & & \\
\hline $\begin{array}{l}\text { Terdapat petunjuk yang jelas tentang } \\
\text { cara mengerjakan soal }\end{array}$ & 5 & Sangat Baik \\
\hline Terdapat pedoman penskoran & 5 & Sangat Baik \\
\hline $\begin{array}{l}\text { Gambar atau cerita disajikan dengan } \\
\text { jelas dan terbaca }\end{array}$ & 5 & Sangat Baik \\
\hline $\begin{array}{l}\text { Kesesuaian soal literasi sains dengan } \\
\text { materi yang diberikan }\end{array}$ & 5 & Sangat Baik \\
\hline $\begin{array}{l}\text { Keakuratan data dan fakta yang } \\
\text { disajikan dalam bentuk soal }\end{array}$ & 5 & Sangat Baik \\
\hline $\begin{array}{l}\text { Memberi motivasi dalam pengerjaan } \\
\text { soalberdasarkan bukti atau fakta yang } \\
\text { ada dilingkungan }\end{array}$ & 5 & Sangat Baik \\
\hline Total & 52 & Sangat Baik \\
\hline
\end{tabular}

Berdasarkan hasil dari penilaian ahli materi yang telah dianalisis untuk mengetahui validitas instrumen tes literasi sains. Adapun hasil validasi yang telah dianalisis sebagai berikut.

Tabel 10

Hasil Analisis Validasi Ahli Media/Desain

\begin{tabular}{|c|c|c|c|}
\hline Aspek yang dinilai & Indikator Penilaian & Nilai/ Skor & Kategori \\
\hline \multirow[t]{12}{*}{ Desain } & Kualitas kertas yang digunakan & 4 & Baik \\
\hline & $\begin{array}{l}\text { Penyajian cover, daftar isi dan } \\
\text { instrumen tes }\end{array}$ & 4 & Baik \\
\hline & Tampilan ukuran dan bentuk soal & 4 & Baik \\
\hline & $\begin{array}{l}\text { Kesesuaian desain instrumen tes } \\
\text { dengan karakteristik materi }\end{array}$ & 4 & Baik \\
\hline & $\begin{array}{l}\text { Kualitas sajian desain dalam } \\
\text { bentuk buku simple dan menarik }\end{array}$ & 4 & Baik \\
\hline & Konsistensi tampilan desain & 4 & Baik \\
\hline & $\begin{array}{l}\text { Jenis dan ukuran huruf yang } \\
\text { digunakan }\end{array}$ & 4 & Baik \\
\hline & Efisiensi soal dan gambar & 4 & Baik \\
\hline & Urutan penyajian & 4 & Baik \\
\hline & Hasil cetakan dan penjilidan & 4 & Baik \\
\hline & Tampilan fisik & 4 & Baik \\
\hline & Total & 44 & Baik \\
\hline
\end{tabular}

Berdasarkan keseluruhan penilaian kevalidan instrumen tes literasi sains yang diberikan oleh ketiga ahli yaitu ahli bahasa, ahli materi dan ahi media terhadap instrumen tes literasi sains pada tema VIII lingkungan sahabat kita untuk siswa kelas V SD Negeri 2 Sugihwaras. Rekapitulasi hasil keseluruhan penilaian kevalidan dari ke tiga ahli dapat dilihat pada tabel berikut: 
3787 Pengembangan Instrumen Tes Literasi Sains pada Tema 8 Lingkungan Sahabat Kita untuk Siswa Sekolah Dasar - Tuhim Setia Ulva, Dian Samitra, R. Angga Bagus Kusnanto

DOI: https://doi.org/10.31004/basicedu.v5i5.1394

Tabel 11

Hasil Tanggapan Tim Ahli

\begin{tabular}{ccccc}
\hline No & Validator & $\begin{array}{c}\text { Skor yang } \\
\text { diperoleh }\end{array}$ & Rata-rata & Kategori \\
\hline 1 & Desain & 44 & 4 & Sangat Baik \\
\hline 2 & Kebahasaan & 56 & 4,3 & Sangat Baik \\
\hline 3 & Isi/ Materi & 52 & 4,7 & Sangat Baik \\
\hline & Total & $\mathbf{1 5 2}$ & $\mathbf{4 , 3}$ & Sangat Baik \\
\hline
\end{tabular}

Berdasarkan tabel di atas diperoleh rata-rata sebesar 4,3 yang masuk ke dalam kategori $x>3,4$ dengan keterangan sangat baik atau dapat dikatakan valid. Maka dari itu instrumen tes literasi sains pada tema VIII lingkungan sahabat kita untuk siswa kelas V SD Negeri 2 Sugihwaras dinyatakan valid dari validitas bahasa. Berdasarkan tabel di atas analisis materi diperoleh rata-rata 4,7 yang masuk ke dalam kategori $x>3,4$ dengan keterangan sangat baik atau dapat dikatakan valid. Maka dari itu instrumen tes literasi sains pada tema VIII lingkungan sahabat kita untuk siswa kelas V SD Negeri 2 Sugihwaras dinyatakan valid dari validitas materi. Berdasarkan tabel di atas analisis media atau desain diperoleh rata-rata 4 yang masuk ke dalam kategori $x>3,4$ dengan keterangan sangat baik atau dapat dikatakan valid.

\section{Hasil Uji Kepraktisan Guru dan Siswa}

1) Uji Kepraktisan Guru

Uji kepraktisan bahan ajar dilakukan dengan ibu Supartiyah, S. Pd. SD. Selaku guru kelas V SD Negeri 2 Sugihwaras pada tanggal 31 Juli 2021 pada lembar kepraktisan guru terdapat 11 pertanyaan untuk menjadi panduan guru menilai instrumen tes literasi sains yang dikembangkan. Berikut hasil respon guru setelah menggunakan instrumen tes literasi sains pada tema VIII lingkungan sahabat kita untuk siswa kelas V SD Negeri 2 Sugihwaras. Aspek yang diberikan melalui lembar respon guru mendapatkan kategori sangat praktis. Hasil rekap guru dapat dilihat pada penilaian angket terbuka sebagai berikut:

Tabel 12

Hasil Analisis Uji Kepraktisan Guru

\begin{tabular}{ccc}
\hline Kode Guru & Jml. Skor & Kategori \\
\hline Wali kelas & 52 & Sangat praktis \\
\hline Rata-rata & 4,7 & Sangat Praktis \\
\hline Hasil & $94,55 \%$ & Sangat Praktis \\
\hline
\end{tabular}

Berdasarkan hasil angket kepraktisan guru yang diperoleh, dapat disimpulkan bahwa respon guru terhadap bahan ajar buku pendamping berbasis kontekstual adalah sangat praktis dengan persentase 94,55\% sehingga bahan ajar dapat digunakan dalam proses pembelajaran.

2) Uji Kepraktisan siswa

Berdasarkan angket yang diberikan kepada peserta didik pada uji one to one dan uji kelompok kecil ini menunjukkan hasil sangat positif terhadap instrumen tes literasi sains. Hasil siswa pada uji one to one dan uji kelompok kecil dapat dilihat pada penilaian angket sebagai berikut:

Tabel 13

Hasil Angket Uji Coba One to One dan Kelompok Kecil

\begin{tabular}{ccccc}
\hline Kode Guru & Jml. Skor & Rata-rata & Presentase & Kategori \\
\hline Uji One To One & 41 & 3,7 & $93,18 \%$ & Sangat praktis \\
\hline
\end{tabular}



Sekolah Dasar - Tuhim Setia Ulva, Dian Samitra, R. Angga Bagus Kusnanto DOI: https://doi.org/10.31004/basicedu.v5i5.1394

\begin{tabular}{ccccc}
\hline Uji Kelompok Kecil & 81 & 7,3 & $92,05 \%$ & Sangat Praktis \\
\hline Total & $\mathbf{1 2 2}$ & $\mathbf{1 1}$ & $\mathbf{9 2 , 4 2 \%}$ & Sangat Praktis \\
\hline
\end{tabular}

Berdasarkan angket uji coba one to one dan uji kelompok kecil yang diperoleh, dapat disimpulkan bahwa respon siswa terhadap instrumen tes literasi sains dengan persentase 93,18\%. Hal ini menunjukkan bahwa instrumen tes literasi sudah praktis dan siap digunakan pada pembelajaran.

\section{Tahap Evaluation (Evaluasi)}

Pengembangan instrumen tes literasi sains pada tema lingkungan sahabat kita dievaluasi pada tahap validasi ahli media, ahli bahasa dan ahli materi. Tahap analisis yang dilakukan telah sesuai dengan kurikulum yang berlaku. Evaluasi kevalidan dalam instrumen tes literasi sains, dilakukan dengan mengadakan evaluasi tim ahli. Evaluasi tim ahli dilakukan oleh tiga ahli yaitu ahli desain, ahli bahasa dan ahli materi. Hasil evaluasi tim ahli berupa angket menjadi standar patokan apakah instrumen tes yang dikembangkan valid atau tidak.

Berikut ini hasil revisi dari para ahli setelah mendapatkan masukan dan saran, setelah direvisi atau diperbaiki sesuai dengan saran dan masukkan dari para ahli diuraikan secara rinci melalui tabel 4.11 berikut ini:

\section{Tabel 14}

\section{Revisi dari para ahli validasi}

\begin{tabular}{|c|c|c|c|}
\hline No. & Validasi & $\begin{array}{l}\text { Sebelum revisi } \\
\text { (saran ahli) }\end{array}$ & Sesudah revisi (hasil revisi) \\
\hline 1. & Ahli Bahasa & $\begin{array}{l}\text { 1. pahami penggunaan kalimat } \\
\text { yang efektif. } \\
\text { 2. pahami penggunaan tanda } \\
\text { baca, dan cara pengetikan. } \\
\text { 3. Penomoran }\end{array}$ & $\begin{array}{l}\text { 1. Penggunaan kalimat efektif } \\
\text { dan Bahasa yang baku sesuai } \\
\text { PUEBI sudah diperbaiki } \\
\text { 2. Penggunaan tanda baca dan } \\
\text { cara pengetikan sudah } \\
\text { diperbaiki } \\
\text { 3. Penomoran sudah diperbaiki }\end{array}$ \\
\hline 2. & Ahli materi & $\begin{array}{l}\text { 1. Perhatikan keefektifan kalimat } \\
\text { dalam pembuatan soal } \\
\text { 2. Typo (terdapat kesalahan } \\
\text { penulisan dalam kalimat) } \\
\text { 3. Batasan jawaban harus } \\
\text { disesuaikan dengan soal }\end{array}$ & $\begin{array}{l}\text { 1. Keefektifan kalimat yang } \\
\text { digunakan sudah diperbaiki } \\
\text { 2. Perbaikan huruf Typo atau } \\
\text { kesalahan penulisan sudah } \\
\text { diperbaiki } \\
\text { 3. Batasan jawaban sudah } \\
\text { disesuaikan dengan soal }\end{array}$ \\
\hline 3. & Ahli media & $\begin{array}{l}\text { 1. Gambar pada sampul depan } \\
\text { kualitasnya kurang } \\
\text { 2. Konsistensi warna latar } \\
\text { ditulisan (gelap vs terang). } \\
\text { 3. Kualitas pada gambar yang } \\
\text { digunakan (gelap vs terang). }\end{array}$ & $\begin{array}{l}\text { 1. Gambar pada sampul depan } \\
\text { saat di cetak kualitasnya } \\
\text { sudah diperbaiki } \\
\text { 2. Penggunaan warna latar pada } \\
\text { instrument tes telah diperbaiki } \\
\text { sesuai saran } \\
\text { 3. Penggunaan kualitas gambar } \\
\text { pada soal instrumen tes telah } \\
\text { diperbaiki sesuai dengan saran }\end{array}$ \\
\hline
\end{tabular}

Uji coba instrumen tes literasi sains dalam proses mengajar dilakukan dengan metode tanya jawab, penugasan, dan diskusi tentang materi tema 8 lingkungan sahabat kita dalam instrumen tes literasi sains. Berdasarkan hasil kesimpulan penelitian tersebut, maka penggunaan instrumen tes literasi sains sudah valid dan praktis untuk digunakan dalam proses belajar. 

Sekolah Dasar - Tuhim Setia Ulva, Dian Samitra, R. Angga Bagus Kusnanto

DOI: https://doi.org/10.31004/basicedu.v5i5.1394

\section{KESIMPULAN}

Berdasarkan hasil penelitian dan pengembangan (R\&D) dengan Judul "Instrumen tes literasi sains pada tema 8 lingkungan sahabat kita untuk siswa kelas V SD Negeri 2 Sugihwaras" menghasilkan produk bahan ajar berupa Instrumen tes yang valid dan praktis untuk digunakan. Penelitian ini telah melalui tahap validasi oleh para ahli yang terdiri dari ahli bahasa, ahli materi dan ahli media serta uji coba one to one, uji coba kelompok kecil, serta uji kepraktisan guru. Dapat disimpulkan bahwa Keseluruhan hasil validasi ahli adalah valid, sehingga layak untuk di uji cobakan pada uji coba one to one dan uji coba kelompok kecil. Hasil kepraktisan guru dan siswa memberikan respon sangat baik terhadap Instrumen tes literasi sains yang dikembangkan sehingga dinyatakan sangat praktis untuk digunakan.

Penelitian ini adalah penelitian pengembangan, sehingga memberikan saran untuk keperluan pemanfaatan produk yang dihasilkan. Produk yang dihasilkan dari penelitian ini diharapkan dapat menjadi referensi guru kelas $\mathrm{V}$ dalam kegiatan pembelajaran.

\section{UCAPAN TERIMA KASIH}

Terimakasih kepada orangtua yang selalu memotivasi saya untuk menyelesaikan tulisan ini, kepada Bapak Dian Samitra dan Bapak R. Angga Bagus Kusnanto yang telah membimbing saya, sehingga penulisan ini dapat selesai tepat pada waktunya.

\section{DAFTAR PUSTAKA}

Kusnanto, R. A. B. (2019). Paradigma Pendidikan Seni; Belajar Melalui Seni Dalam Pendidikan Anak Usia Dini. Https://Ejournal.Unsri.Ac.Id/, 6 No 2, 155-162.

Lestari, F., Egok, A. S., \& Febriandi, R. (2020). Pengembangan Bahan Ajar Matematika Berbasis Problem Based Learning Pada Siswa Kelas V SD. Ilmu Pendidikan, 18 No 3, 255-269. Https://Doi.Org/Http://Dx.Doi.Org/10.31851/Wahanadidaktika.V18i3.4395

Melati, E. R., \& Utanto, Y. (2016). Kendala Guru Sekolah Dasar Dalam Memahami Kurikulum 2013. Indonesian Journal of Curriculum And Educational Technology Studies, 4(1), 1-9. Https://Doi.Org/10.15294/Ijcets.V4i1.14252

Minan, M. A., \& Suhendro, E. (2020). Pengembangan Kurikulum Berbasis Tahfidzal_Qur'an Dan Kitab Kuning Pada Madrasah Umum Di Mts Mabdaul Huda Karangaji. Pendidikan Bahasa Arab, 1, No 02, $27-37$.

Novanti E. K. S., Yulianti E., M. R. V. (2018). Pengembangan Instrumen Tes Literasi Sains Siswa Smp Materi Tekanan Zat Dan Penerapannya Dalam Kehidupan Sehari-Hari. Jurnal Pembelajaran Sains, 2(2009), 6-12.

Samatowa. (2018). Metode Pembelajaran Sains Untuk Pendidikan Anak Usia Dini (1st Ed.). Tira Smart.

Samitra, D., Krisnawati, Y., \& Malasari, N. (2018). Pengaruh Model Guided Note Taking Terhadap Hasil Belajar Biologi SMA. BIOEDUSAINS: Jurnal Pendidikan Biologi Dan Sains, 1(1), 1-10.

Santoso, E. (2017). Penggunaan Model Pembelajaran Kontekstual Untuk Meningkatkan Kemampuan Pemahaman Matematika Siswa Sekolah Dasar. Jurnal Cakrawala Pendas, 3(1). Https://Doi.Org/10.31949/Jcp.V3i1.407

Sartilah, F. Satria, T. G, \& Firduansyah, D. (2021). Pengembangan Lembar Kerja Siswa Berbasis Saintifik Pada Mata Pelajaran Seni Budaya Kelasiv SD Negeri 41 Kota Lubuklinggau. Wahana Didaktika: Jurnal Ilmu Kependidikan, 19 No. 1, 38-52.

Satria, T. G, \& Egok, A. S. (2020). Pengembangan Etnosains Multimedia Learning Untuk Meningkatkan 
3790 Pengembangan Instrumen Tes Literasi Sains pada Tema 8 Lingkungan Sahabat Kita untuk Siswa Sekolah Dasar - Tuhim Setia Ulva, Dian Samitra, R. Angga Bagus Kusnanto

DOI: https://doi.org/10.31004/basicedu.v5i5.1394

Kognitif Skill Siswa Sd Di Kota Lubuklinggau. Basicedu, 4 No 1, 13-21.

Seran, E. Y., \& Suani, V. L. (2019). Pengaruh Model Pembelajaran Kooperatif Tipe Picture And Picture Terhadap Hasil Belajar Ips Siswa Kelas Iii Sd. Pengaruh Model Pembelajaran Kooperatif Tipe Picture And Picture Terhadap Hasil Belajar Ips Siswa Kelas Iii Sd, 1 (1), 1-8.

Setiawan, A. R. (2020). 298-885-1-Pb. Pembelajaran Tematik Berorientasi Literasi Saintifik, 4(1), 51-69.

Sohibun. (2017). Pengembangan Media Pembelajaran Berbasis Virtual Class Berbantuan Google Drive. Jurnal Keguruan Dan Ilmu Tarbiyah, 02 (2), 121-129. Https://Doi.Org/10.24042/Tadris.V2i2.2177

Sudijono. (2011). Pengantar Evaluasi Pendidikan (1st Ed.). Kharisma Putra Utama.

Sugiyono. (2019). Metode Penelitian Kuantitatif Kualitatif (Sutopo (Ed.); Cetakana K).

Suryani, N, Setiawan A, \& P. A. (2018). Media Pembelajaran Inovatif Dan Pengembangannya (Pipih Latifah (Ed.); 1 st Ed.). PT. Remaja Rosdakarya.

Tegeh, I. M., \& Pudjawan, I. N. J. K. (2015). Pengembangan Buku Ajar Model Penelitian Pengembangan Dengan Model ADDIE. Seminar Nasional Riset Inovatif IV, 208-216.

Yuliati. (2017). Literasi Sains Dalam Pembelajaran IPA. Cakrawala Penda, 3 (2), 21-28.

Zaenal Arifin. (2017). Kriteria Instrumen Dalam Suatu Penelitian. Jurnal THEOREMS (The Original Research Of Mathematics), 2(1), 28-36.

Zubaidillah, M. H. (2018). Prinsip Dan Alat Evaluasi Dalam Pendidikan. 1-13. Https://Doi.Org/10.31219/Osf.Io/4tgfm 